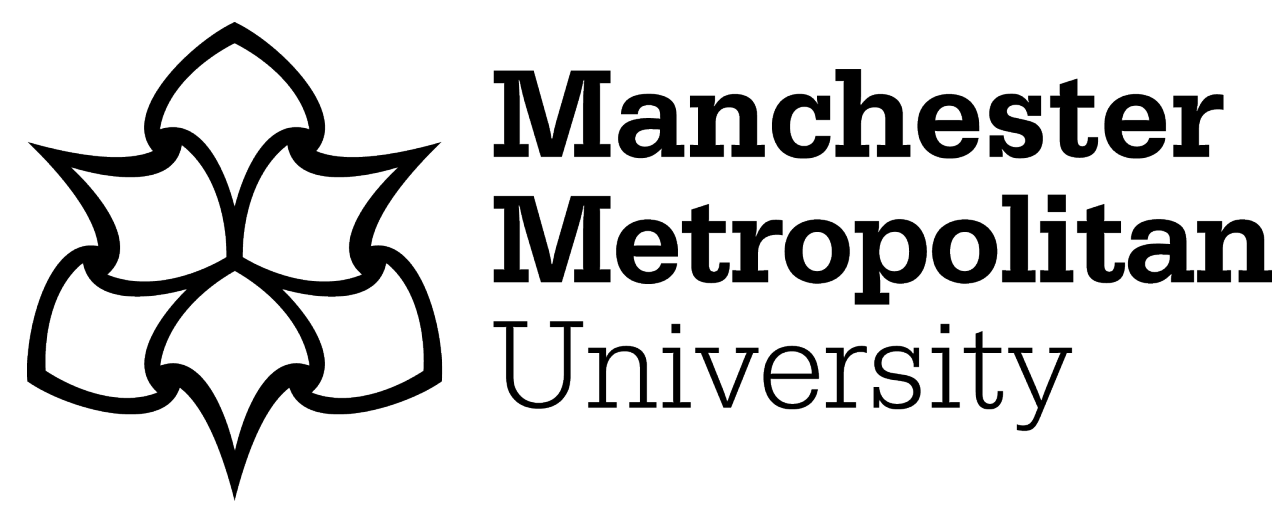

Paucar-Caceres, AL ORCID logoORCID: https://orcid.org/0000-0002-4690561X, Dos Santos, R, Wright, G ORCID logoORCID: https://orcid.org/00000003-2183-711X and Belderrain, MC (2020) Soft situational strategic planning (SSSP): a method and case study of its application in a Brazilian municipality. Journal of the Operational Research Society, 71 (3). pp. 363-380. ISSN 0160-5682

Downloaded from: https://e-space.mmu.ac.uk/622938/

Version: Accepted Version

Publisher: Taylor \& Francis

DOI: https://doi.org/10.1080/01605682.2019.1568840

Please cite the published version 


\section{Soft situational strategic planning (SSSP): \\ A method and case study of its application in a Brazilian municipality}

\section{Alberto Paucar-Caceres}

Manchester Metropolitan University Business School

All Saints Campus, Oxford Road, Manchester, M15 6BH, UK

a.paucar@mmu.ac.uk

2. Paloma Ribeiro dos Santos

ITA - Instituto Tecnológico de Aeronáutica

Praça Marechal Eduardo Gomes, 50 -

Vila das Acácias, São José dos Campos - SP, Brazil

paloma@ita.br

\section{Gillian Wright}

Manchester Metropolitan University Business School

All Saints Campus, Oxford Road, Manchester, M15 6BH, UK g.wright@mmu.ac.uk

4. Mischel Carmen Neyra Belderrain

ITA - Instituto Tecnológico de Aeronáutica

Praça Marechal Eduardo Gomes, 50 -

Vila das Acácias, São José dos Campos - SP, Brazil

carmen@ita.br 


\begin{abstract}
Municipal government planning is challenging in the extreme being characterised by illstructured and messy problems, the complexity of which is compounded by often conflicting views and priorities of multiple stakeholders. In South America, Situational Strategic Planning (SSP) is a wide spread method of such planning. The purpose of this paper is to explore the use of a proposed multi-methodological approach, Soft Situational Strategic Planning (SSSP) in a South American municipal government. SSSP is a variant of SSP enhanced with elements of Soft Systems Methodology (SSM) and Strategic Choice Approach (SCA). Through an action research case study in a Brazilian municipality, we implemented SSSP through a strategic planning cycle. The findings suggest that SSSP complement the SSP process regarding the implementation and monitoring of strategy. The application also indicated that SSSP has the potential to make government planning processes more structured for policy makers.
\end{abstract}

KEYWORDS: Problem structuring; Situational Strategic Planning; Government Planning; Soft Systems Methodology; Strategic Choice Approach 


\section{Introduction}

The core challenge faced by managers in municipal government is that of balancing the achievement of policy objectives set by political leaders, with achieving efficiency in the deployment of resources. In this paper, this strategic planning challenge is regarded as a complex, unstructured problem, with multiple actors, perspectives, conflicting interests and intangible issues that are difficult to measure. These features meet the criteria of a situation that lends itself to a Problem Structuring Methods (PSM) approach (Rosenhead, 2006, Mingers, 2001a, Mingers, 2001b, Mingers and Rosenhead, 2004) and this is the approach we take to the strategic challenges of municipal government in Latin America.

In Latin America, Strategic Situational Planning (SSP) is a widely known and used method of strategic planning in municipal governments (Matus, 1993a, Giacomini, 2008, Bernazza, 2006, Aguerrondo and Xifra, 2011, Huertas, 1996); SSP was proposed by the Chilean former Minister of Economy, Carlos Matus ${ }^{1}$ during the 1970s. Essentially, SSP aims to improve the, to some extent, ineffective traditional (normative) approach used previously in strategic planning. In Latin America, the principles of SSP are acknowledged for their conceptual ideology and Brazil was one of the first countries to embrace it (Matus, 1993b). In the strategic management of municipal governments Latin America systems thinking and associated practical applications is relatively unexplored as an approach to compliment SSP, though we assert that it can be used effectively to build on SSP and so develop contemporary approaches to the strategic planning process.

This paper suggests just such a development of the SSP approach based on a multimethodological approach to of strategic planning for municipal governments utilizing two approaches of Soft Operations Research: Soft Systems Methodology (SSM) (Checkland, 1972, Checkland and Scholes, 1990, Checkland and Poulter, 2006) and Strategic Choice Approach (SCA) (Friend and Hickling, 2004). The relevance of this research to the OR community derives from the importance of the situation to multiple stakeholders, the complexities of the environment and the intricacies of the SSP approach.

\footnotetext{
${ }^{1}$ Carlos. Matus started his career as a researcher and teacher on the field of public planning and management at the UN Economic Commission for Latin America (ECLA) in Santiago. He was a member of Salvador Allende's government (1970-1973) and fulfilled the functions of Minister of Economy and Head of the Central Bank. At the coup he was imprisoned with other ex-ministers at the prison of the Island of Dawson (extreme south of Chile). In 1976 he was exiled to Venezuela, where he resumed his work as a UN expert and started developing PES, through the organisation of seminars and the publication of books. In 1987 he founded ALTADIR, a specialised research and training institute on the field of public steering.
} 
Although the four moments of SSP (Explanatory, Normative, Strategic and TacticalOperational) seem to be logical and flexible in theory, the method does not address the detail of its implementation and the interaction of actors; so, we argue that there is scope to incorporate more structure at the practical planning stage into the method. We assert that this can be done by grafting stages of two widely known PSMs: SSM and SCA.

This paper proposes a multi-methodological approach to strategic planning for municipal governments which we name Soft Situational Strategic Planning (SSSP). SSSP is based on Matus's SSP as a platform on which two 'Soft' operational research methodologies, Soft Systems Methodology (SSM) and Strategic Choice Approach (SCA) are grafted. Following four phases of SSP as an overall structure, we embed into them the first three stages of SSM (exploring the situation, expressing it and encapsulating it in a root definition) to aid the understanding of the problematic situation; and the design mode advocated by SCA to help relate goals to the main issues and to define strategies. We have deliberately used stages or elements of SSM and SCA that have been the most used in multi-methodological practice (Munro and Mingers, 2002). In doing this we demonstrate how, by using the proposed 'Soft' SSP adapted framework, an approach enhanced with the most well-known elements of SSM and SCA, strategic planning can be facilitated and we would argue, improved.

This paper addresses the need for a structured approach to the implementation of strategic planning in local government by considering how the four moments or stages of SSP can be adapted, enhanced and operationalised to simplify its application to municipalities, thus providing a roadmap to planning. Specifically, the aim of the research is to explore the use of an amended strategic planning tool, SSSP, to assist in the strategic planning in Brazilian local municipalities. This paper reports how the proposed method, SSSP, was applied in our case study of a local municipality and the behavioural aspects of the actors involved in a strategic planning intervention associated with the process.

This paper makes a number of contributions. First it advocates the SSSP framework with which to structure and implement planning in municipal government. Second it contributes to PSM practice and in particular, to the debate as to how PSMs can be combined in a multimethodological framework to yield more effective results in a systemic intervention. Thirdly the application of SSSP presented in this paper demonstrates that the practical experience accumulated during the implementation process can assist public planners in carrying out the complex strategic planning process in a more effective fashion. Finally, for Operational 
Research practitioners, this demonstrates, with a practical case, how 'Soft' OR could help to simplify the process of strategic planning of municipal governments, by enhancing the widely used SSP with elements of Soft Systems Methodology (SSM) and Strategic Choice Analysis (SCA).

The paper is organised as follows. In section 2 we address SSP in some detail, explaining its main features, the rationale for using a multi-methodological approach and the nature of our proposed SSSP approach. Section 3 describes our approach to the fieldwork, a case study based on an action research intervention in a Brazilian Local Municipality, and the steps of the strategic planning methodology that were implemented during the intervention. Section 4 describes the implementation in practice and presents a full account of the outcomes and the resulting strategic priorities of the intervention along with the ways in which the actors responded. Finally, section 5 comprises our conclusions together with a discussion of limitations and our thoughts on further research.

\section{Situational Strategic Planning (SSP)}

This section describes the origins of SSP as a strategic tool in Latin America. It then briefly addresses multi-methodology in Management Science as a preamble to describing the combination of SSP with SCM and SSM in an approach that we call Soft Situational Strategic Planning (SSSP).

\subsection{Origins}

SSP is a public strategic planning method designed to serve the government and political leaders in addressing public problems, but can be applicable to any institution that has a political, economic and social centre of play (Huertas, 1996). The SSP method works with public problems, from a situational analysis, a strategy is developed that is used to guide operations within a plan that is a strategic bet on the future. It does not seek to predict the future, but to create it from the treatment of uncertainties seeking to discover possibility and anticipate answers.

SSP was developed to improve on the traditional, so called Normative Planning, previously adopted in Latin American countries. From experience in planning in Latin American 
countries, Carlos Matus emphasised the importance of the situational context in strategic planning in his initial proposal for a strategic planning approach in Chile.

Carlos Matus came to prominence in the late 1960s and his ideas sparked an epistemological rupture with respect to normative planning (Giacomini, 2008). He began to develop his ideas as Head of Advisory Division of the Institution of Latin American Economic and Social Planning (ILPES), confirming his break from Normative Planning as a government official under President Salvador Allende in the 1970s. From prison, he wrote his critique of Normative Planning. In Venezuela, from 1977, he began the development of the method of "Planificación Estrategica Situacional" (known as PES in Spanish), widely known as Situational Strategic Planning (SSP). In his book (Matus, 1980), he outlined the need for a theory of social action planning. In the mid-1980s he wrote his book Theory of Social Game which was eventually published by Fundação do Desenvolvimento Administrativo (Matus, 2005). In the meantime, he wrote "Política, Planejamento \& Governo", presenting his social planning theory, which was the foundations of "Planificación Estrategica Situacional" and the four moments of the situational planning process (Matus, 1993b). This was followed by "Adios, Señor Presidente" (Matus and FUNDAP, 1996) covering government practices in Latin America and "Chimpanzé, Machiavelli y Gandhi" (Matus, 1996) commenting on how the action of an actor may be conditioned by the action of another and is closely related to social game theory. He died, aged 83, in 1998 in Venezuela.

At its core, SSP suggests that stakeholders - actors - may have different interpretations and explanations of an existing situation, and that furthermore, as situations change over time, a strategic plan must be adapted to this change (Matus, 1997). SSP assumes that that the plan can be effective only if it is one that addresses current problems in a participative way, and tries to envisage future scenarios. This in same way resonates with Soft OR preoccupations when it tries to deal explicitly with how solutions to a problem can account for different views (Liebl, 2002). Taking planners as participators and performers, SSP allows for the consideration of a multiplicity of perceptions of the nature of problems, taking SSP beyond the normative approach (Matus and FUNDAP, 1996) in serving government and political leaders in solving public service problems (Huertas, 1996). There are six key critiques of normative planning and associated assumptions that must be accommodated in SSP (Silva et al., 2009). These critiques illustrate the different paradigms underpinning normative planning and situational strategic planning (SSP) are placed. SSP is clearly aligned to the interpretivist camp whereas the normative approach leans towards the positivistic tradition. These are summarised in Table 1. 
Table 1: Comparative Assumptions of Normative and Situational Strategic Planning.

\begin{tabular}{|c|c|}
\hline Normative planning & Situational Strategic Planning \\
\hline $\begin{array}{l}\text { The subject and the planned object are } \\
\text { independent. }\end{array}$ & $\begin{array}{l}\text { Planners cannot control reality which depends on } \\
\text { multiple actors. }\end{array}$ \\
\hline There is only one definitive truth in diagnosis. & Multiple actors lead to multiple explanations of reality. \\
\hline $\begin{array}{l}\text { The planned object involves actors with } \\
\text { predictable behaviour. }\end{array}$ & $\begin{array}{l}\text { Various social actors face each other with conflicting } \\
\text { goals. }\end{array}$ \\
\hline Power is not a scarce resource. & $\begin{array}{l}\text { Scarce power requires planners to systematise the } \\
\text { political calculation and focus attention on the } \\
\text { situation. }\end{array}$ \\
\hline Planning references a predictable context. & Uncertainty is predominant. \\
\hline $\begin{array}{l}\text { Goals are self-referenced in a plan for which the } \\
\text { final state is known }\end{array}$ & $\begin{array}{l}\text { Managers work with emergent problems requiring } \\
\text { open solutions requiring creativity and may invoke } \\
\text { conflicts. }\end{array}$ \\
\hline \multicolumn{2}{|c|}{$\begin{array}{l}\text { Source: adapted from: O Planificación Estratégica Situacional no Setor Público - A Contribuição de Carlos } \\
\text { Matus (Silva et al., 2009) }\end{array}$} \\
\hline
\end{tabular}

\subsection{The process of SSP implementation}

The focus of SSP is on situational change, through sequential transformations to reach the preferred or desired situation It provides for the periodic monitoring of the transformations to verify their continuing trajectory towards the objective situation. The SSP processes prescribes a sequence of procedures (Huertas, 1996).

1. Explain the root and development of the problem;

2. Make operational plans to tackle the causes;

3. Analyse the political feasibility and build the viability of the plan and;

4. Attack the problem in practice through planned operations.

These procedures are the "moments" (stages) designated by Matus as: explanatory, normative, strategic and tactical-operational (Santos and Belderrain, 2014). These are flexible and performed in order or iteratively, depending upon the planning need and context.

The explanatory moment consists of encouraging different explanations of the same problem from the perspectives of different actors selecting and analysing the most relevant problems for intervention. Social actors, according to Matus (1997), are social forces and personalities who control centres of power; interpret reality according to their points of view and information they possess. The problems, which may cross sectors, are identified and listed. Present problems give rise to reactive planning whilst potential problems give rise to proactive planning. This first moment explains how problems arise to identify their most critical causes. 
When SSP was applied to planning in the pharmaceutical supply system: "At the moment of explaining the problems prioritized, the brainstorming technique was adopted with the following key questions: "What is causing this problem?", "Why is this occurring?" And "What are the consequences of these problems?" (Cazagrande and Teixeira, 2018).

The normative moment considers possible interventions and the nature of the desired future state. It consists of planning the intervention actions, which are called operations. This moment outlines the plan to achieve the future desired situation in which the problem is solved or minimised in a given time horizon. Though SSP defines the short-term actions of the present government it is focused on long-term situation and outcomes.

In the normative moment the plan is developed at various levels, the most general level of which is the Government Program. According to Matus (1993b), the program expresses the desired direction of change. Another important program is the Directional Program which comprises social interventions capable of achieving a situational change towards the objective situation. The Directional Program (Matus, 1993b) answers questions such as:

- Where do you want to go with situational change?

-What kind of society do you want to build, and with what characteristics?

- What are the reasonable goals and objectives to be achieved by the current government, and what consistency is there in society?

-What will change in society during the present government?

In situational planning operations are the interventions made on the critical nodes of problems and operations are commitments that must be implemented to modify the problem situation (Matus, 1993b). The modular plan is designed in parts conducive to the complexity of the problems, and by its nature it is flexible and adaptable.

During the strategic moment, aspects of the normative moment are evaluated for feasibility of implementation. Actions initially considered unviable are reviewed to develop viability. This evaluation requires actions to be takes account of the politically, economically, technically and organizationally feasible (Matus, 1993b). The plan consists of operations (carried out by the actor responsible for their planning) and "demands for operations" (intended for other actors to perform when the operation is outside the governability of the planner)" and deemed to be constructors of viability as their support makes the operation possible. The feasibility analysis considers two factors: the motivation of the actors and the degree of control the actors have over necessary resources. This moment identifies conflicts in the interests of the actors and the 
relationships between them and also identifies unviable operations. Consensus among the actors leads to the operation being deemed feasible, when there is no consensus the analysis explores whether the motivations in favour are greater than the oppositions. The level of importance attributed by actors to the operation is taken to imply their inclination to allocated appropriate resources to an operation.

Finally, the tactical-operational moment, comprises the operation, execution of the actions and the planned strategies. A structured plan is developed that addresses responsibilities, deadlines, budgets and indicators for monitoring and control. In this phase the plan periodically reviewed and is necessary revised in reaction to the changing environment, simulations are carried out in anticipation of events that may intervene before the objective situation is achieved. Control indicators, include: economic, political, compliance, impact of operations, administrative activity, economic balance sheets, the financial situation, intention and expectations are created to assist directing the plan.

For the monitoring of the plan a situation room is established, a place to collate information on the progress and status of projects to enable redirection decisions to be made in real time.

\subsection{Limitations and criticism in the use of SSP}

Although SSP has been widely used in Latin America (Matus, 1997), its full implementation as a process has been limited and full descriptions and evaluations are not available in the literature. Acknowledging the limitations of SSP, Matus suggested augmentation of SSP with two other approaches: the "Zielorientierte Projektplanung" (ZOPP) and "Método Altadir de Planejamento Popular" (MAPP). The ZOPP and MAPP are used in Latin America by planners in local municipalities, political parties and trade unions. The ZOPP was proposed in 1983 by the German Society for Technical Cooperation (GTZ), as a project planning approach oriented by goals and applied through workshops using visualization techniques to express the different stages of work and results (GTZ, 2013). MAPP is a simplified version of SSP, created by Matus at the Altadir Foundation and allows for the application of planning concepts to contextualise problem situations and select solutions (Baldissera et al., 2012). As a flexible method that can be applied to government departments, rural workers unions, neighbourhood associations, and other organizations, it is an instrument to address problems, reduce complexity and facilitate coping; it is used mainly for situations in which popular participation is required. Another 
visible SSP limitations is that, its procedures are deeply embed in logical analysis and assumes that '...all problems may be analysed in terms linear causal relationships', (Van Vliet, 2006) showing its potency when problems are relatively structured but fails to tackle the complexity of ill-structured, messy situations. Also, and as with any other a participative method, it is highly dependent on the facilitators and this can be a challenging, even a disadvantage. Finally, there can be a tendency to over-formalise and abuse of jargon during the SSP procedure has been detected (Van Vliet, 2006).

\subsection{Multi-methodology in management science, the case for better informed systemic intervention}

Having sketched the main features of SSP, and following (Mingers, 1997b), in this paper, we suggest incorporating some specific features of some Soft OR methodologies into an overall framework to form a new approach. We developed SSSP as a contribution to OR multimethodology practice. In this approach, we suggest the use of detachable parts of specific methodologies (SSM and SCA) by grafting them into SSP to gain a clear and organised approach to planning in local government, thus building a multi-methodological approach. To argue our case for multi-methodology practice and to describe how we have amalgamated these soft PSM, the main theoretical tenets underpinning multi-methodology practice are outlined in the next section.

During the late $90 \mathrm{~s}$, there evolved an intense debate in the systems and OR community around issues concerning the use of more than one methodology (combining them, or parts of them) when intervening in complex situations. The theoretical and practical problems of multi-methodology remain strongly debated topics within the systems domain. One of the main problems facing the practice of multi-methodology is that the practitioner needs to migrate from one paradigmatic stance to another in order to fully understand (being conversant) and apply it. Two further approaches to multi-methodology seem to be: (a) pluralism/complementarism as initiated by Flood and Jackson (1991) and lately developed into 'coherent pluralism' by Jackson; and (b) multi-paradigm multi-methodology / critical pluralism developed by Mingers (1997b). In this paper, we adopt Mingers' multiparadigm multi-methodological pluralistic approach. Multimethodology in management science has been developed and promoted mainly in the UK in the 
late 90s (Mingers and Brocklesby, 1997, Mingers, 2000, Midgley, 1997, Jackson, 1997, Mingers, 1997a).

The debate surrounding the use of various MS/OR methods in an intervention and reports of multimethodology applications has continued and increased over the last decade (Munro and Mingers, 2002, Franco and Lord, 2011, Ferreira, 2013).

Relevant to the combination described in this paper, Mingers (1997a) takes the view that any intervention should gain benefits from being approached with a variety of management science methodologies in what he calls 'strong pluralism' arguing that agent(s), that is person(s) intervening in the situation, would benefit if the intervention is tackled using a 'blend of methodologies'. His arguments in favour of the application of a multiplicity of methodologies are:

a) Some situations are inherently so complex that not a single methodology can claim to be able to tackle it completely, and we should pay attention to three aspects involved in any intervention: material, social and personal. Some methodologies will bring more enlightenment to some of these three aspects than others;

b) An intervention is not a discrete event but continuous, therefore some methodologies are more suitable to certain phases of the intervention. We should not disregard the possibility of combining methodological stages, methods or tools from different methodologies from different paradigms; and

c) There are practical reasons in favour multiparadigm multi-methodology: many systems practitioners have already started to practice it.

To avoid falling into the argument of paradigm incommensurability, in this paper, we argue that the three methods used: Situational Strategic Planning (SSP); Soft Systems Methodology (SSM) and Strategic Choice Approach (SCA) are underpinned, in general, by the interpretivist or learning paradigm in Management Sciences (Paucar-Caceres, 2010).

The framework proposed by Mingers illustrating how different methodologies from the same paradigm might be in single paradigm multi-methodological setting (Mingers, 1997a) is adapted in other research (Paucar-Caceres, 2007), resulting in the four combinations depicted in Figure 1. The case of multi-methodology practice advocated in this paper will be aligned closely to what Mingers (1997a) calls a 'combination of whole/part methodology under one single paradigm'. This is illustrated in Figure 1 (case 4) from (Paucar-Caceres, 2007): Our framework proposes to "enhance" SSP by grafting some stages of SSM and SCA into the general SSP framework resulting in what we coin as 'Soft Situational Strategic Planning' SSSP. 
Paradigm

Methodology

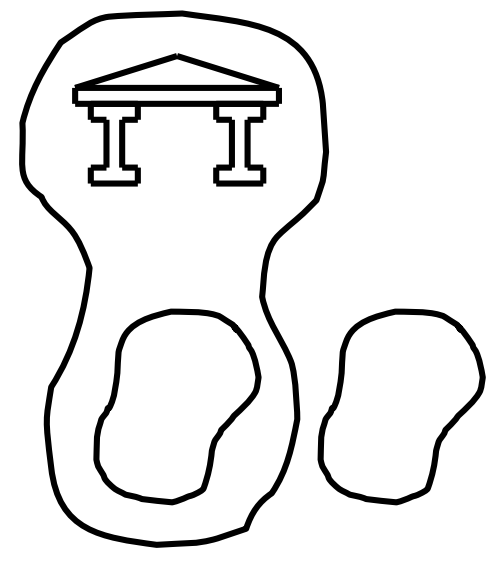

(1) Methodological Isolationism

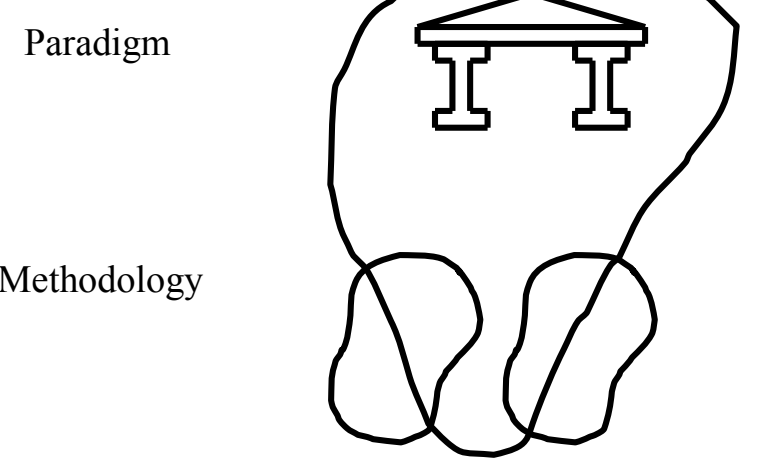

(3) Single Paradigm MultiMethodology

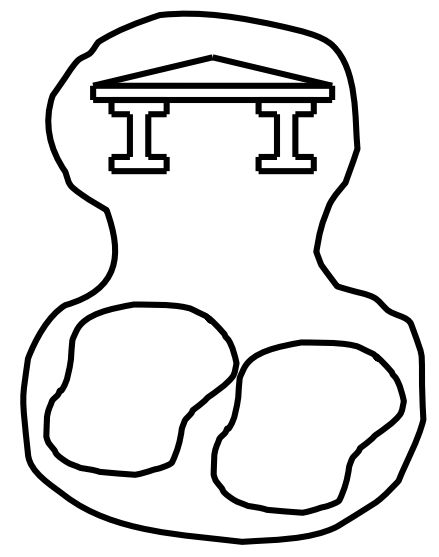

(2) Methodological Combination

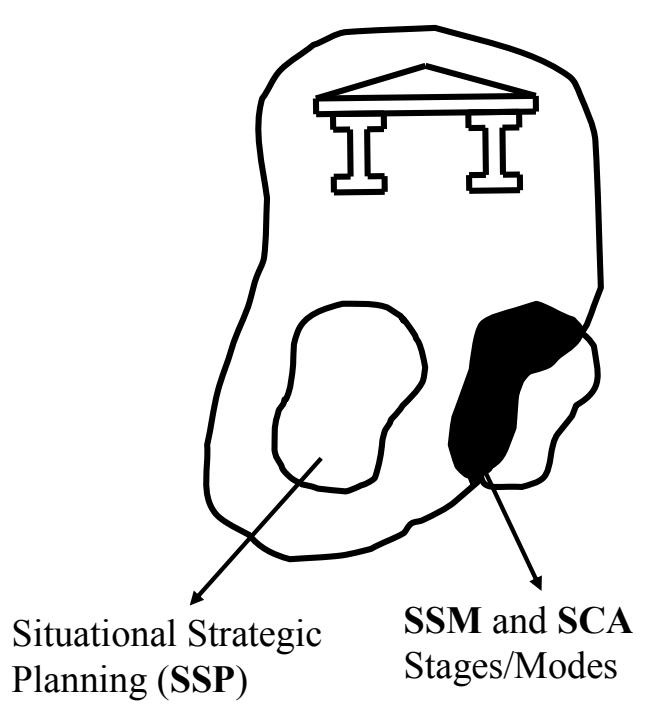

(4) Methodology enhancement Soft Situational Strategic Planning (SSSP)

Figure 1. Styles of Single Paradigm types of methodological Intervention. Case number 4 illustrates Situational Strategic Planning methodology enhanced with SSM and SCA stages. (Adapted from PaucarCaceres 2007 and Mingers, 1997b) 


\subsection{Soft Situational Strategic Planning (SSSP): a synthesis of SSP, SSM and SCA}

In this section, we outline the features of the core contribution of this paper, the proposed framework for 'soft' situational strategic planning (SSSP) method. Based on the four moments of SSP, in Figure 2 we propose our Soft Situational Strategic Planning (SSSP) method, as an integrated framework for strategic decision-making for municipal local government. It comprises four linked phases: Phase 1: Situation Analysis comprising stages 1, 2, and 3 of SSM; phase 2: Solution Development based on CATOWE and mode Designing of SCA; Phase 3: Solutions Prioritization with Mode Comparing of SCA; and Phase 4: Action/Monitoring Plan. It should be noted here that the process of the four phases is not sequential, but rather an iterative process during which the phases are re-visited. In the next sections, we describe each of these phases, indicting how the four moments of SSP are adapted to incorporate elements of the PSM approaches of SSM and SCA. 


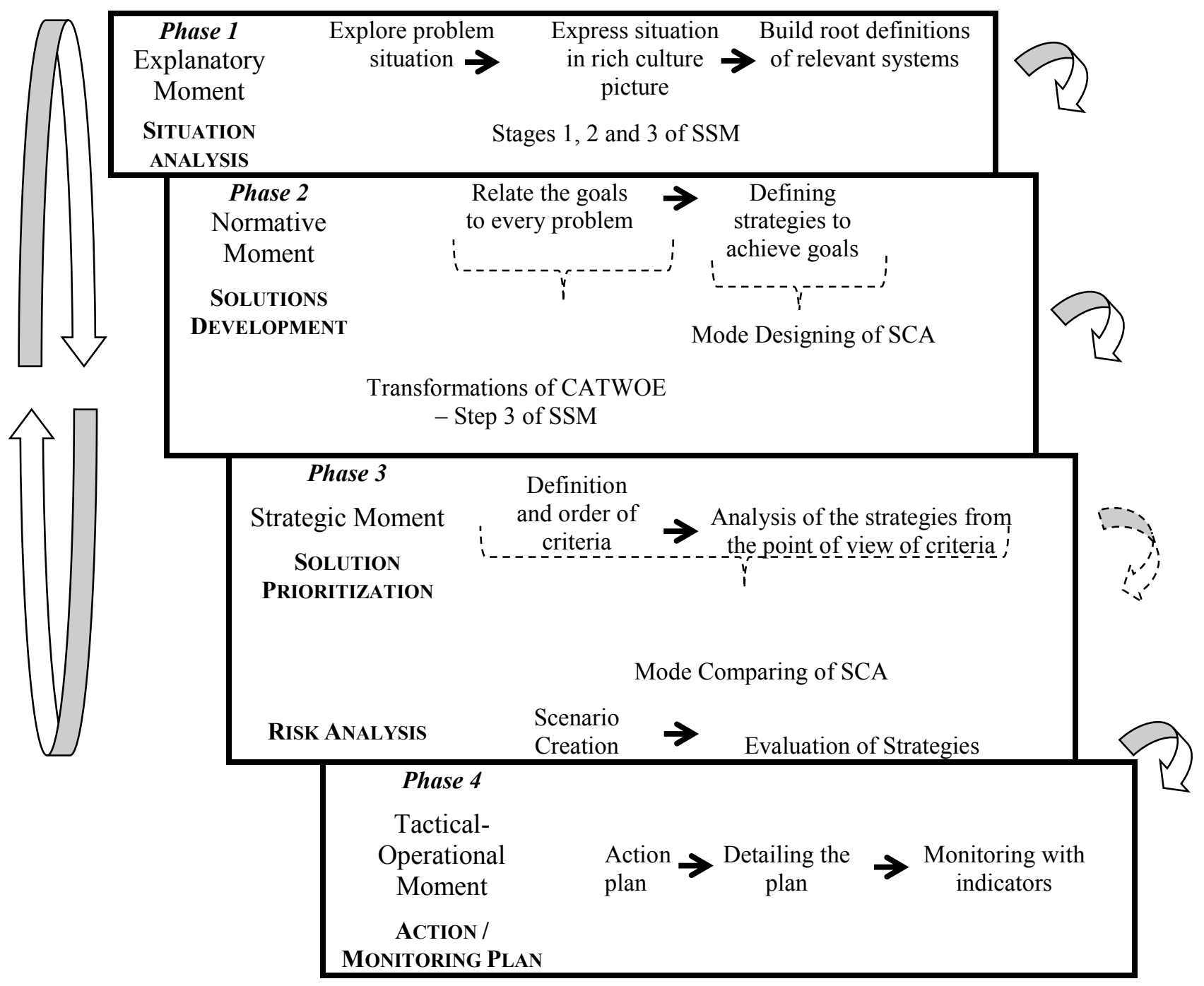

Figure 2. Soft Situational Strategic Planning (SSSP): A Framework for Integrated Method of Strategic Planning. 


\subsubsection{Phase 1. Situation Analysis}

SSSP Phase 1 equates to the Explanatory moment of SSP, seeking to understand the societal context from stakeholder viewpoints. We have incorporated SSM stages to develop an agreed description of the problems: rich picture to explore and depict problem situation, expressing it via root definitions aided by CATWOE analysis. After understanding the situation in terms of the agents, relationships and influences, a rich picture is constructed to explore interrelationships. CATWOE (Clients; Actors; Transformation; Weltanschauung; Owners and Environment) is then used to build root definitions of selected strategies. The rich picture, root definition and CATWOE analysis are powerful SSM tools that help to air the different perspectives and perceptions of the actors, and to understand the processes and environment elements contributing to the complexity of the problem situation.

Strategic planning of municipal governments is regarded as comprising complex, ill-structured, messy problems, the complexity arising from the, sometimes conflicting, views of multiple stakeholders.

Initially, all participating public managers contribute their knowledge, understanding and feelings about the current situation. A moderated discussion explores problems and needs of the city, the systems and associated issues they consider pertinent to planning along with internal and external issues important to, and influential on, the municipality. This leads to the production of a rich picture and, with the aid of the moderator, the problems with greatest impact on the city and actors in the society are listed. The final step in phase 1 is to build root definitions of relevant systems based on level of impact, practical feasibility of intervention and political interests affecting government strategy; a time-consuming step that may elicit much debate. The Design Mode of SCA, multiple decision options, that are, as far as possible, mutually exclusive, are suggested for each area. In this approach however, we propose that that complementary strategies may be taken forward for evaluation.

We used stages 1, 2 and 3 of SSM in an iterative process to obtain a Rich Picture of the situation. Some RD and CATWOE were drafted and discussed informally with governmental planners, to facilitate Rich Picture as the base for the next stage of SSSP. At the end of the two workshops, and after three weeks, a Rich Picture was produced depicting the situation. This Rich Picture was produced as the basis for the next SSSP stage. 


\subsubsection{Phase 2. Solutions Developments}

SSSP Phase 2 corresponds to normative moment of SSP and comprises the two steps of relating the goals to every problem and defining strategies to achieve the goals. We propose a transformation step (the T of CATWOE), in which only one goal is related to each problem. The designing mode of the Strategic Choice Approach (SCA) is also used in phase 2 of the SSSP. SCA has been used extensively in public organizations, and hence it seems a suitable to use some of it features within SSSP. Congruent with the decision options element of SCA, strategies to address how each transformation may be achieved are suggested and considered for viability. This phase draws on a two-stage implementation of SCA first to relate goals to every problem and then to define potential strategies. Possible strategies for each problem are all considered regarding their priority and for feasibility.

In the traditional design mode, the process of analysing the feasibility of alternatives considers all the combinations of the strategy decision options. Alternatively, the number of choices subjected to analysis can be reduced if strategies are grouped by problem rather than taking each strategy individually, which is the approach taken here, and the difference in the number of analyses is demonstrated in Figure 3.

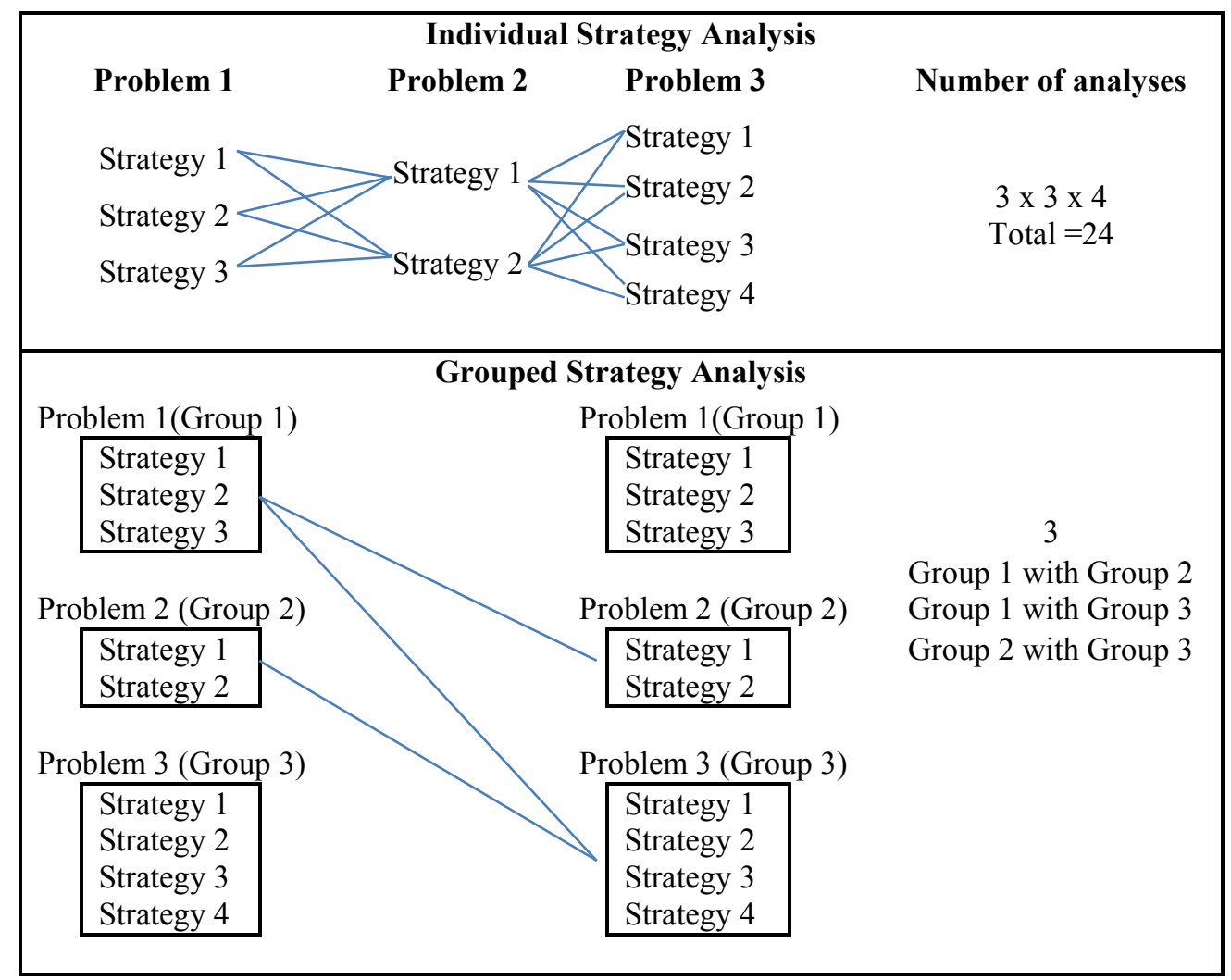


Figure 3. Approaches to strategy feasibility analysis.

\subsubsection{Phase 3: Solutions Prioritization and Risk Analysis}

SSSP Phase 3 equates to the Strategic moment of SSP in which strategies are selected and prioritised. The comparing mode of the SCA is used to define the criteria and their order of priority. In SSSP the criteria are defined by the actors albeit within the prevailing political, economic, social and technological factors. Each strategy is evaluated by actors for their potential performance on each criterion. A score is given (1-10) for each strategy against each criterion by the actors to assist understanding the possible behaviour of strategies and these scores are totalled. Low scoring strategies may be amended at this stage to increase viability or alternatively may be considered too high a risk or unfeasible and thus discarded. The scoring thus facilitates evaluation, comparison and shortlisting/rejection of proposed strategies.

\subsubsection{Phase 4: Action and Monitoring Plan}

Finally, in SSSP stage 4, the tactical-operational moment, a schedule of actions is developed. It was considered in three parts: an action plan with responsibilities, deadline, a budget and monitoring plans; the detailed actions of the plan with the wider implementation team; provision of monitoring information to the Directorate. The perspectives taken in monitoring comprised Benefits for Citizens/Society, Government Relations, Learning Growth and Internal Processes and, Budgetary Perspectives (Felix et al., 2011).

\section{Research approach}

Our research approach was an action research case study of the application of the Soft Situational Strategic Planning (SSSP) approach, to strategic planning in a local municipality in Brazil. In line with an action research approach, this research is based on a situation in which researchers and professionals undertake applied research to solve an extant problem (Kelly and Walker, 2004), it is a 'form of action inquiry that employs recognised research techniques to inform the action taken to improve practice' (Tripp, 2005). The present study can be regarded as an action research exercise: the perspective we adopted was to make neither the ideas nor the practical experience dominant and that the intention was to allow the tentative ideas to inform our practice (Checkland, 1981, Checkland, 1999). Furthermore, we did not set out to be normative in our findings, but rather we adhere to a phenomenological approach: we proposed a multi-methodological framework with the intent of deriving theoretical insights 
(for the OR community) from a real case with real-world data very much in line with the suggestion of Eden and Huxham (1996).

SSP as an approach to strategic planning has been widely used in cities in Brazil including: Betim (MG), Ipatinga (MG), Santos (SP), Piracicaba (SP), Campinas (SP), Porto Alegre (RS), Rio Branco (AC), Natal (RN), Maraba (PA), Parauapebas (PA), Belém (PA), among others (Gonçalves, 2005), so this type of methodology was reasonably familiar to participants. The proposed SSSP methodology was applied when one of the researchers was given access to the case as the moderator of the strategic planning process. The researcher was employed by a consultancy organisation, IPPLAN (Instituto de Pesquisa, Administração e Planejamento) whose role is to advice municipal governments. IPPLAN (http://www.ipplan.org.br/) is nonprofit organisation. This consultancy was contracted by the local municipality government to carry out strategic planning. In this way, the research intervention was legitimised as a part of the regular strategic planning activities of the company.

The strategic planning of municipal governments is regarded as a complex and systemic problem due to the number of factors involved, the relationships and agendas of actors and the importance of the impact of the resulting decision. The planning process needs to consider the factors involved in maintaining the balance between public and other stakeholder interests bringing benefits to the city through planned actions in an organised manner.

Time is a scarce resource for public managers in the current political situation of the Local Municipality and so use of moderators experienced in the use of strategic planning methods and the organization of planning meetings is commonplace. The moderator has the responsibility of planning the approach to strategic planning, they set the process, determine the method to be used and manage the dynamics of the meetings. In our case, the moderator was tasked to facilitate the auxiliary strategic planning process and chose the SSSP as a means of achieving this.

The proposed SSSP method was applied with the secretariat over two meetings on $1^{\text {st }}$ March and $11^{\text {th }}$ December 2015. The first meeting was a 5.5-hour away-day workshop; a location other than the workplace was deemed appropriate to prevent the temptations of distraction and partial or sporadic attendance. The second event was in the situation room and lasted five hours. The workshops were led by a moderator (one of the authors of the paper) assisted by one researcher assistant who helped with notes and the photographic record. 
The same seven people from the Strategic Planning Secretariat, including the Secretary, participated in both workshops. These participants all had managerial functions as Heads of Division and Directors. The Secretary invited them as people who could make decisions, and though, for some, it was their first participation in such an event, all delegates made good contributions.

The process and outcomes of our intervention are described in the following section 4 in which the narrative comprises a descriptive account of both the nature of the activities and the situational experiences of implementing the case including the interactions of the actors (Ormerod, 2014). We describe in detail the technical nature of the intervention, and comment on the process of the implementation, the roles, responses and interaction of the actors (Ormerod, 2014). We identify contextual circumstances, and difficulties that influenced the progress of the intervention to help readers understand the reality of the context and to understand and make sense of the findings when reading this case with a view to undertaking similar case research themselves (Ormerod, 2017).

\section{An Application of Soft Situational Strategic Planning (SSSP) to Municipal Government Planning}

The Municipality/City Hall is the centre of political decisions and where actors maintain the relationships of Governance, it is the location of the office of the Mayor who is responsible for the interests of society. Local Municipality planning had been undertaken two years previously and defined the projects that would be developed in the four subsequent years of management. In 2015 the Local Municipal Government identified the need to review their situation and reconsider the projects that would be executed by the secretariats during 2015-2016, adapting them to prevailing capacity and governance, specifically in light of the economic crisis that threatened the country.

\subsection{Phase 1: The Situation Analysis}

During the initial planning stages of the consultation, the situation exploration, in phase 1 , the moderator was active in direct observation and undertook a series of stakeholder interviews with planners, internal and external stakeholders. After three weeks, following the SSM approach, a rich picture was produced, first by the researcher working in the organisation, then 
discussed with the wider research team for clarity. Finally, it was circulated amongst participants and fine-tuned so that it was agreed as a realistic depiction of the situation, resulting in the rich picture depicted in Figure 4. The purpose was to depict the organization's climate through understanding its structure and process and the interaction between these (Checkland, 1981). In constructing the RP, the authors used the SSM guidelines to remain open to the various issues emerging from the systems identified in the case. The purpose was to depict the organization's structure and process and the interaction between these, its climate (Checkland, 1981). The Rich Picture was circulated and discuss among the main stakeholders who expanded and add elements to it. After various iterations, the team produced the picture depicted in Figure 4. The configured problematic situation that the proposed method tackles is shown using a rich picture (as used in SSM) depicted in Figure 4.

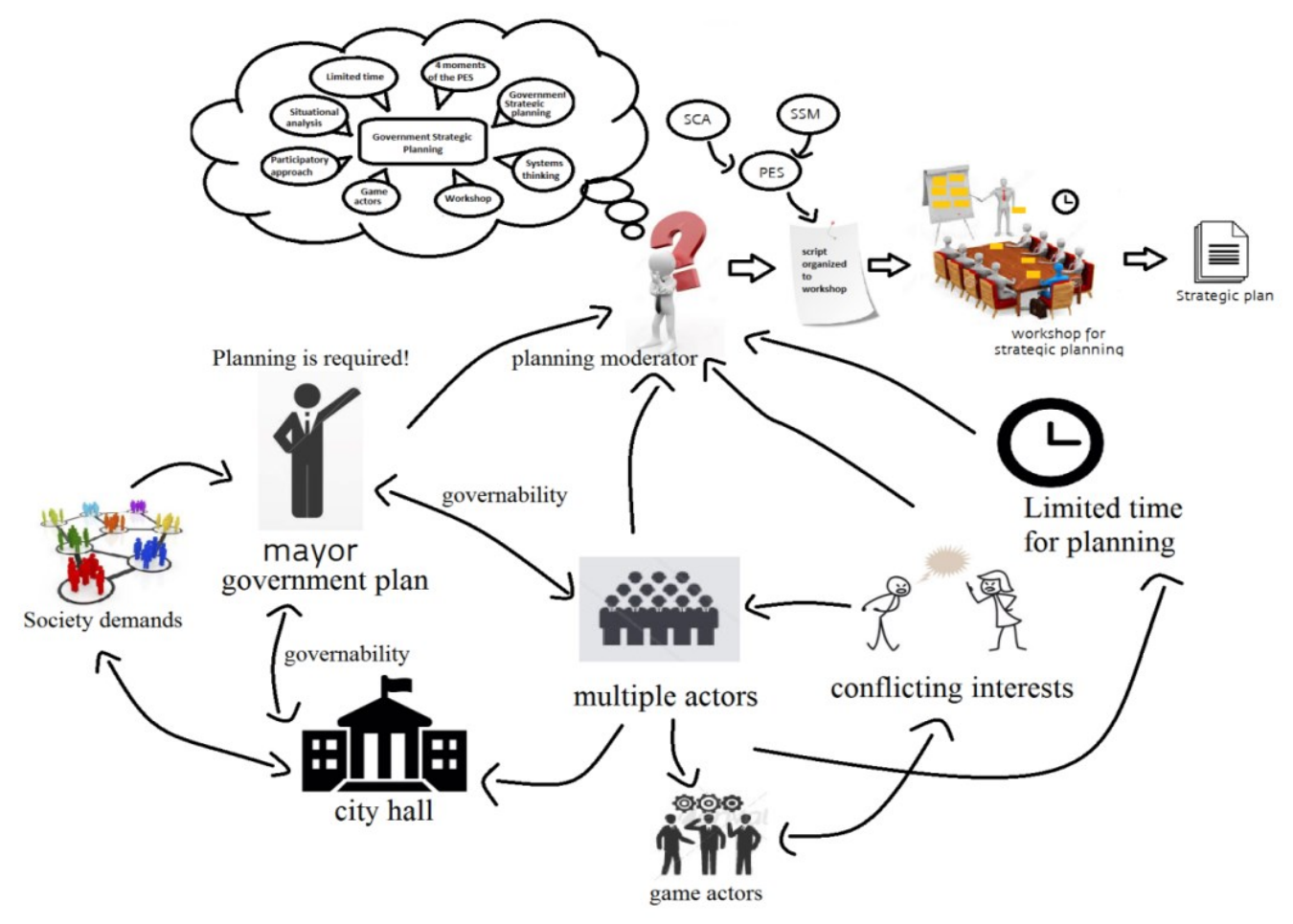

Figure 4 Rich Picture of the Problematic situation.

The written lists from the participants were posted on a board to allow visualization. Based on these lists, participants considered the actors that interacted with each problem, and these lists joined the problems on the board. A map of the connections between problems and actors was 
built to illustrate a systemic view of relationships of influence and identify how the problems were interlinked. This map is reported here as Figure 5.

During the workshop, the moderator provided coloured cards on which the participants noted their ideas; this facilitated the participation of all, even the most quiet, participants. In the periods of debate, the work of the moderator was greater as there was the added task of maintaining a balance across the explanations from individuals. Reflecting on the process, the research team realised that this was an important role and the moderator needed to ensure that the group remained in control and that the purpose of the workshop was achieved, they felt that the behaviour of the group and thus the outcome of the planning process was, to a great extent, a result of the approach of the moderator.

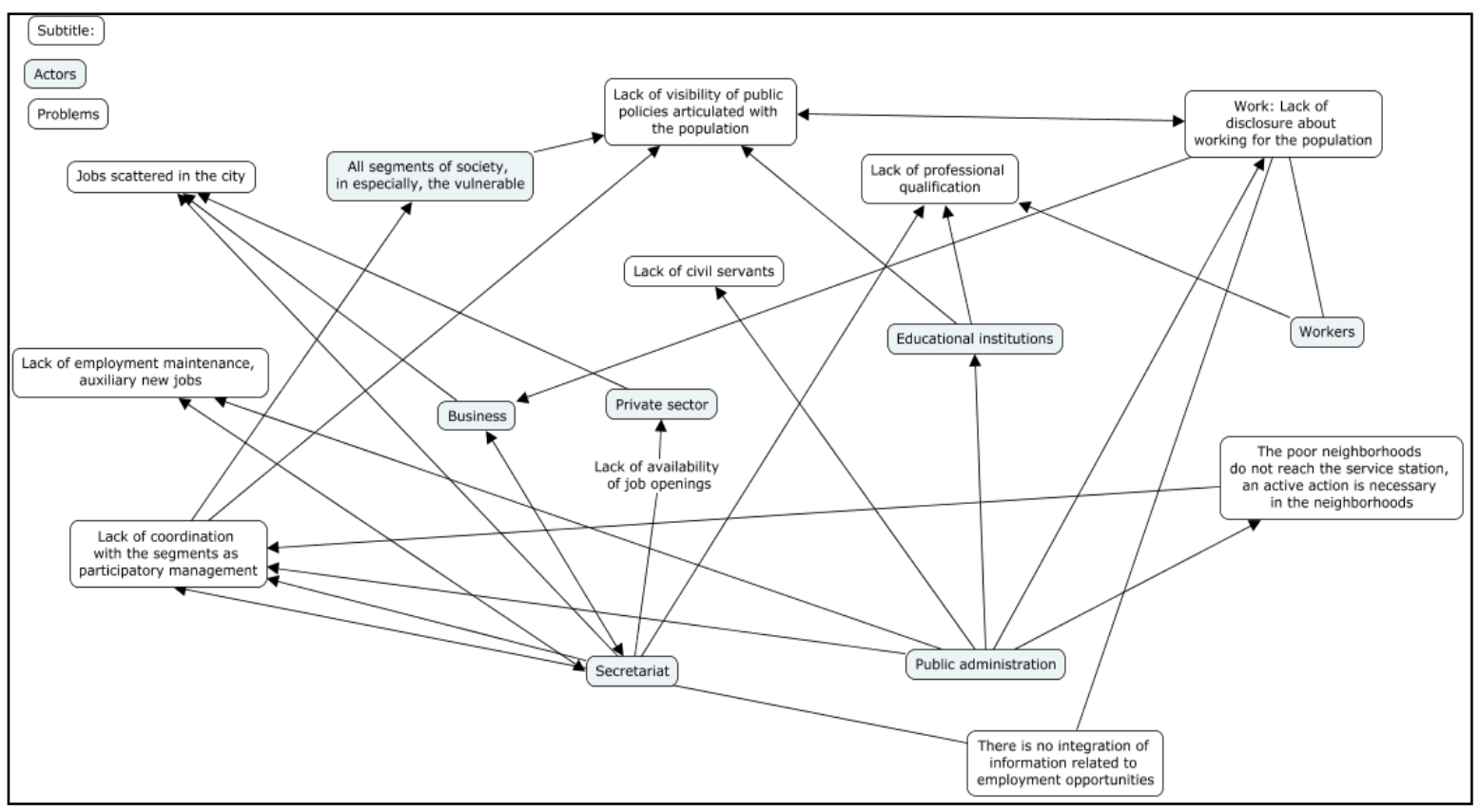

Figure 5. Relationship of influence between the problems and actors.

\subsection{Phase 2: Solutions Developments}

We followed SSM approach (see section 2.4.1) to distinguish areas of concern. As a result of this, nine relevant systems were identified; from these, five were chosen, by the participants, to take forward for further consideration using the CATWOE criteria. We then drew on the design mode of SCA to consider potential solutions to the five problems, first by defining desired outcomes and then by suggesting projects to achieve these. These five problems, associated projects (interventions) and targets are summarised in the first part of Table 2 . The 
bottom part of Table 2 depicts the possible interfaces between the projects; no project was considered to have a possible potential negative interference with any others. The feasibility of implementation was verified by inspecting the groups of strategies following the "strategy feasibility analysis' in Figure 3. For example, 'Cities Fully Qualified for Work' and 'Work and Income', are two strategies/projects that were analysed to identify feasibility of execution together with 'Communication's Work Plan'; 'Mobile Service Station'; 'Conferences, forums, debates and Labour Observatory'; and 'Municipal Employment System'.

Table 2. Problems, Projects, Targets and Strategy Interference Analysis

\begin{tabular}{|c|c|c|}
\hline Selected Problems & Projects & Target \\
\hline $\begin{array}{l}\text { Interdepartmental bureaucratic barriers to } \\
\text { public and private projects that would } \\
\text { stimulate job creation and maintenance }\end{array}$ & $\begin{array}{c}\text { Cities Fully Qualified for } \\
\text { Work } \\
\text { Work and Income }\end{array}$ & $\begin{array}{l}\text { Integrated action of secretariats } \\
\text { with companies }\end{array}$ \\
\hline $\begin{array}{l}\text { Lack of public visibility of policies and } \\
\text { strategic actions }\end{array}$ & Communication's Work Plan & Have communication strategies \\
\hline $\begin{array}{l}\text { Lack of employment opportunities and } \\
\text { qualifications for peripheral city areas }\end{array}$ & Mobile Service Station & Have a service structure on site \\
\hline $\begin{array}{l}\text { Lack of articulation with organizations } \\
\text { through participatory management }\end{array}$ & $\begin{array}{c}\text { Conferences, forums, debates } \\
\text { Labour observatory }\end{array}$ & Enhance existing joints \\
\hline Jobs scattered across the city & $\begin{array}{c}\text { Municipal Employment } \\
\text { System } \\
\end{array}$ & Centralise employment agency \\
\hline \multicolumn{3}{|c|}{ Interfaces and feasibility analysis } \\
\hline $\begin{array}{l}\text { Cities Fully Qualified for Work } \\
\text { Work and Income }\end{array}$ & Citi & $\begin{array}{l}\text { Fully Qualified for Work } \\
\text { Work and Income }\end{array}$ \\
\hline \multicolumn{3}{|c|}{ Communication' s Work Plan } \\
\hline \multicolumn{3}{|r|}{ Mobile Service Station } \\
\hline $\begin{array}{c}\text { Conferences, forums, debates } \\
\text { Labour observatory }\end{array}$ & $\mathrm{Co}$ & $\begin{array}{l}\text { ferences, forums, debates } \\
\text { Labour observatory }\end{array}$ \\
\hline Municipal Employment System & Mun & cipal Employment System \\
\hline
\end{tabular}

\subsection{Phase 3: Prioritization of Solutions and Risk Analysis}

In phase 3, projects were prioritised in the light of political, economic and technological factors (equally weighted); the intent was to prioritise projects of greatest interest and impact taking ability to execute them into account. Political factors included government visibility and political time; the economic factor was financial viability and the technological factor was 
concerned with capability of execution. A brief description of the nature and objectives of each project is presented below:

Cities fully qualified for work - courses and lectures for workers leading to professional qualifications increase employability of citizens.

Achieving more work and income - the creation of new and sustainable jobs through partnerships of government agencies with universities and System S (Senai, Sesc, Sesi).

Communication of opportunities - to increase the visibility of public policies aimed at workers through communicating the initiatives of the Local Municipality available to its citizens.

Mobile service station - a mobile information facility promoting job openings to facilitate higher levels of employment.

Conferences and debates for the worker - periodic events to help workers promote themselves in the workplace.

Labour observatory - analysis of the economic environment and activities to better advise workers.

Municipal employment system - provides information on the requirements of specific business sectors and available positions in them.

Two further projects which were already being implemented by the secretariat were identified for inclusion by the participants:

Centre for Autonomy Support - help for self-employed workers to analyse the market demand for their offerings.

Solidarity economy - the creation income generating centres with specific publics including: female victims of violence, family farming, recyclable materials and cooperatives and to create the legislation necessary for the institution at the local level of the Solidarity Economy.

Participants debated the projects and criteria aided by an explanation of the evaluation criteria which served to avoid problems with this process. Each participant scored the elements of the three factors from 1-10 for all strategies and overall scores calculated (Table 3). The project Communication Work Plan was removed because the actors believed that this project should be analysed together with other departments on a broader level. Strategies scoring 25 or more were selected: System Municipal Employment; Cities Fully Qualified for Work; Achieving More Work and Income; Holding Conferences, Forums and Debates for the Worker; and Mobile Service Station. 
Table 3. Evaluation of Projects

\begin{tabular}{|c|c|c|c|c|c|c|}
\hline \multicolumn{7}{|c|}{ Evaluation template } \\
\hline Scoring criteria & High 8,9,10 & \multicolumn{3}{|c|}{ Medium 4,5,6,7 } & \multicolumn{2}{|c|}{ Low $0,1,2,3$} \\
\hline $\begin{array}{l}\text { Government } \\
\text { visibility }\end{array}$ & $\begin{array}{l}\text { Guaranteed recognition } \\
\text { by the local population }\end{array}$ & \multicolumn{3}{|c|}{$\begin{array}{l}\text { Guaranteed recognition by } \\
\text { beneficiaries and organizations }\end{array}$} & \multicolumn{2}{|c|}{$\begin{array}{l}\text { No guaranteed recognition, } \\
\text { possible negative impact }\end{array}$} \\
\hline Political time & $\begin{array}{l}\text { Completed by June } \\
2016\end{array}$ & \multicolumn{3}{|c|}{$\begin{array}{l}\text { Significant implementation and } \\
\text { visibility by June } 2016\end{array}$} & \multicolumn{2}{|c|}{$\begin{array}{l}\text { Not possible to deploy by } \\
\text { June } 2016\end{array}$} \\
\hline \multirow[t]{2}{*}{$\begin{array}{l}\text { Financial } \\
\text { viability }\end{array}$} & $\begin{array}{l}100 \% \text { of guaranteed } \\
\text { resources. }\end{array}$ & \multicolumn{3}{|c|}{$\begin{array}{l}\text { External resources, no return } \\
\text { guarantee }\end{array}$} & \multicolumn{2}{|c|}{ No available resources } \\
\hline & & \multicolumn{3}{|c|}{$\begin{array}{l}\text { Partial Treasury resources needed for } \\
\text { possible external provision }\end{array}$} & & \\
\hline $\begin{array}{l}\text { Execution } \\
\text { capability }\end{array}$ & Existing capability & \multicolumn{3}{|c|}{ External capability possible } & \multicolumn{2}{|c|}{$\begin{array}{l}\text { No existing or potential } \\
\text { contracted capability }\end{array}$} \\
\hline \multicolumn{7}{|c|}{ Project Scores } \\
\hline \multicolumn{2}{|c|}{ Project Name } & $\begin{array}{l}\text { Government } \\
\text { visibility }\end{array}$ & $\begin{array}{c}\text { Political } \\
\text { time }\end{array}$ & $\begin{array}{l}\text { Financial } \\
\text { viability }\end{array}$ & Capability & Total score \\
\hline \multicolumn{2}{|c|}{ Cities fully qualified for work } & $\mathrm{H}-10$ & $\mathrm{H}-10$ & $\mathrm{H}-10$ & $\mathrm{H}-10$ & 40 \\
\hline \multicolumn{2}{|c|}{ Conferences, forums, debates } & H-9 & H-9 & L-0 & $\mathrm{H}-8$ & 26 \\
\hline \multicolumn{2}{|c|}{ Mobile service station } & H-9 & $\mathrm{H}-8$ & L-0 & $\mathrm{H}-8$ & 25 \\
\hline \multicolumn{2}{|c|}{ Achieving more work and income } & $\mathrm{H}-10$ & M-7 & L-0 & $\mathrm{H}-8$ & 25 \\
\hline \multicolumn{2}{|c|}{ Municipal employment system } & $\mathrm{H}-8$ & $\mathrm{H}-8$ & L-0 & $\mathrm{H}-9$ & 25 \\
\hline \multicolumn{2}{|c|}{ Solidarity economy } & M-7 & $\mathrm{H}-9$ & L-0 & $\mathrm{H}-8$ & 24 \\
\hline \multicolumn{2}{|c|}{ Centre for Autonomy Support - CAS } & M-7 & M-7 & L-3 & M-7 & 24 \\
\hline \multicolumn{2}{|c|}{ Labour observatory } & $\mathrm{H}-8$ & M-7 & L-0 & M-7 & 22 \\
\hline
\end{tabular}

This stage included the consideration of scenarios of major events in politics, the economy and society that could impact on the progress of the strategies. The four scenarios considered were: municipal elections with associated uncertainty of the continuity of government; a new economic crisis in the local municipality; a national economic crisis and the 2016 Olympics. Participants were asked to consider how the strategy would perform and if it could be continued under each scenario. A summary of the likely impact of the scenarios is summarised in Table 4. 
Table 4. Evaluation of the projects: scenario risk analysis

\begin{tabular}{lcccc}
\hline Scenario & $\begin{array}{c}\text { Municipal } \\
\text { elections }\end{array}$ & $\begin{array}{c}\text { New municipal } \\
\text { economic crisis }\end{array}$ & $\begin{array}{c}\text { National } \\
\text { economic crisis }\end{array}$ & 2016 Olympics \\
\hline $\begin{array}{l}\text { Municipal } \\
\text { employment system }\end{array}$ & Maintains & Continues & $\begin{array}{c}\text { Continues, but is } \\
\text { compromised }\end{array}$ & $\begin{array}{c}\text { Continues and } \\
\text { improves services }\end{array}$ \\
\hline $\begin{array}{l}\text { Cities fully qualified } \\
\text { for work }\end{array}$ & Continues & $\begin{array}{c}\text { Continues on a } \\
\text { smaller scale }\end{array}$ & $\begin{array}{c}\text { Continues on a } \\
\text { smaller scale }\end{array}$ & $\begin{array}{c}\text { Continues with } \\
\text { specific adaptations }\end{array}$ \\
\hline $\begin{array}{l}\text { Conferences forums } \\
\text { and debates }\end{array}$ & $\begin{array}{c}\text { Can become fixed } \\
\text { on the calendar }\end{array}$ & $\begin{array}{c}\text { May interfere } \\
\text { positively or } \\
\text { negatively }\end{array}$ & $\begin{array}{c}\text { May interfere } \\
\text { positively or } \\
\text { negatively }\end{array}$ & Continues \\
\hline $\begin{array}{l}\text { Achieving more } \\
\text { work and income }\end{array}$ & $\begin{array}{c}\text { Continues, can be } \\
\text { reformulated }\end{array}$ & $\begin{array}{c}\text { Continues on a } \\
\text { smaller scale }\end{array}$ & $\begin{array}{c}\text { Continues on a } \\
\text { smaller scale }\end{array}$ & Continues \\
\hline $\begin{array}{l}\text { Mobile service } \\
\text { station }\end{array}$ & $\begin{array}{c}\text { Continues, can be } \\
\text { reformulated }\end{array}$ & Continues & $\begin{array}{c}\text { Continues, but is } \\
\text { compromised }\end{array}$ & Continues \\
\hline
\end{tabular}

\subsection{Phase 4: The Action Plan}

In phase 4 , the action plan was determined, participants defined overall and support responsibilities, then the budgets and start/end dates. The detailed plan was produced by the participants after the planning event, coordinated by the moderator. After nine months, the strategies were evaluated on the basis of whether actions had been implemented and the results achieved. This information is summarised in Table 5. This table reports the actors, budget and start and end dates for each strategy. Each strategy is then reported in its component parts and for each of these the start and end dates, responsibility (initials) and the criteria for monitoring is included with the percentage achieved. Throughout the workshop the material produced was displayed on the panels, the actors could observe what had already been done and this served to encourage them to appreciate that the day, and indeed the strategies, were productive. 
Table 5: Action plan: Strategy teams, budgets, schedules and monitoring.

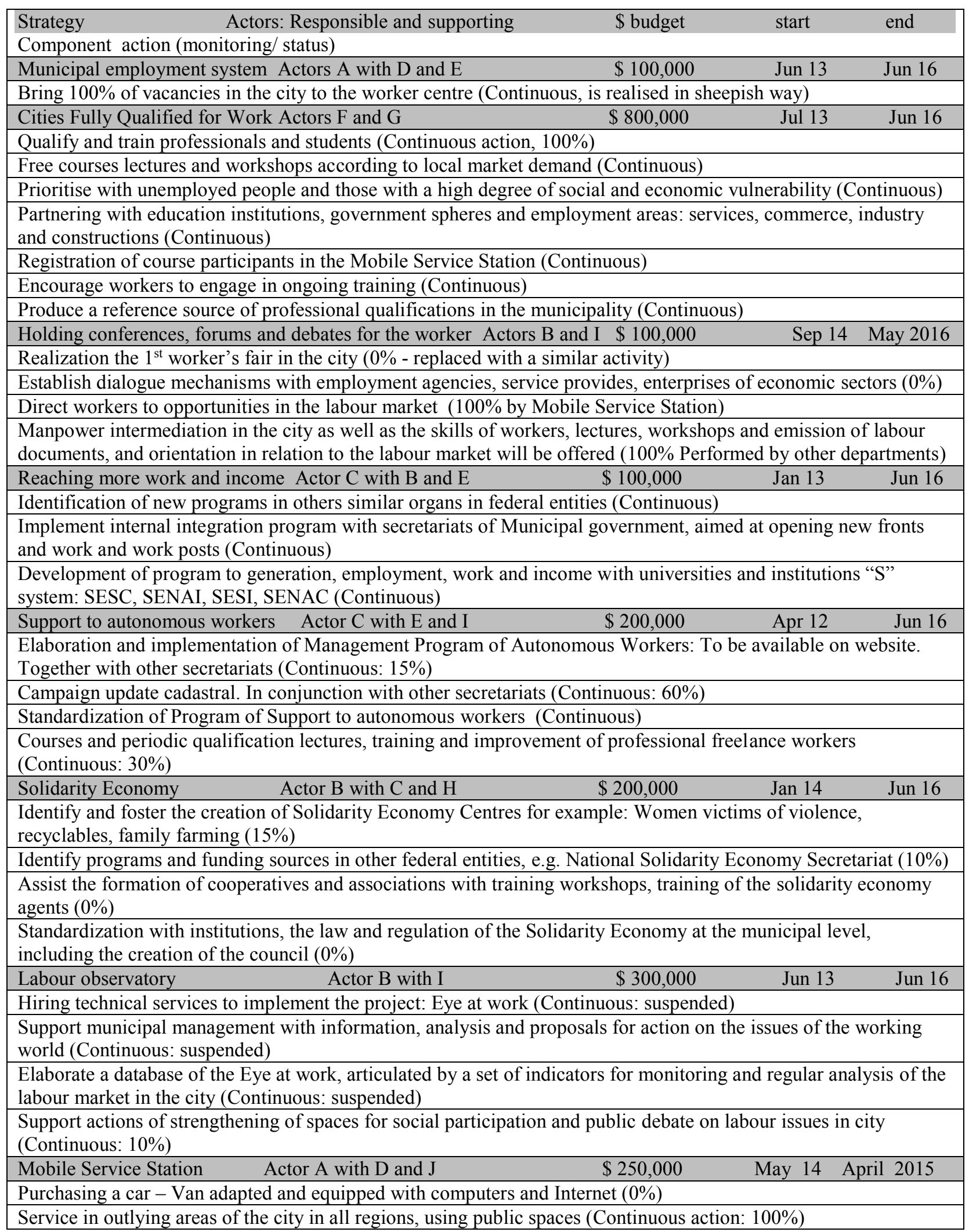


Monitoring was concerned with both strategy implementation and outcomes in terms of: Government relations, learning and growth in internal processes and benefits for citizens/society which are the three government concerns when developing strategy (Table 6). Projects Eye at Work and Solidarity Economy were not evaluated because they had few actions realised. Table 6 shows budgets and spend on of each strategy -most did not receive the expected resources and were made possible by the resources of the Secretariat or by support from other projects.

Table 6: Priority factor and budget outcomes

\begin{tabular}{|c|c|c|c|c|}
\hline & \multicolumn{2}{|c|}{ Government relations } & $\begin{array}{l}\text { Learning and growth } \\
\text { and internal processes }\end{array}$ & Citizen / society \\
\hline $\begin{array}{l}\text { System Municipal } \\
\text { Employment }\end{array}$ & \multicolumn{2}{|c|}{$\begin{array}{c}\text { Visibility and more } \\
\text { openness with the state }\end{array}$} & Team harmony (mostly) & Offer of opportunities \\
\hline $\begin{array}{l}\text { Conferences and } \\
\text { debates }\end{array}$ & \multicolumn{2}{|c|}{ Cooperation of institutions } & $\begin{array}{l}\text { Quest to realise strategy } \\
\text { through alternative }\end{array}$ & Better knowledge \\
\hline $\begin{array}{l}\text { Mobile Service } \\
\text { Station }\end{array}$ & \multicolumn{2}{|c|}{$\begin{array}{l}\text { Execution in conjunction } \\
\text { with another project }\end{array}$} & Effort and unity team & Proximity of the population \\
\hline $\begin{array}{l}\text { Centre for } \\
\text { Autonomous Service } \\
\text { - CAS }\end{array}$ & \multicolumn{2}{|c|}{$\begin{array}{l}\text { Promising approach to } \\
\text { generating work and income }\end{array}$} & $\begin{array}{l}\text { Developed new internal } \\
\text { systems and procedures }\end{array}$ & $\begin{array}{c}\text { Promotes inclusion of } \\
\text { autonomous employed } \\
\text { Provides emergency services }\end{array}$ \\
\hline $\begin{array}{l}\text { Cities Fully } \\
\text { Qualified for Work }\end{array}$ & \multicolumn{2}{|c|}{ Positive: with high visibility } & $\begin{array}{l}\text { Effective in implementing } \\
\text { the project }\end{array}$ & $\begin{array}{l}\text { Better quality of life } \\
\text { More job opportunity }\end{array}$ \\
\hline Work and Income & $\begin{array}{l}\text { Mediat } \\
\text { cooper }\end{array}$ & $\begin{array}{l}\text { tion sindicato } \\
\text { ative courses }\end{array}$ & $\begin{array}{c}\text { Knowledge of processes to } \\
\text { instigate courses }\end{array}$ & $\begin{array}{c}\text { Maintenance of work and \$ } \\
\text { Access to courses }\end{array}$ \\
\hline \multicolumn{5}{|c|}{ Budget outcomes } \\
\hline $\begin{array}{l}\text { Cities Fully } \\
\text { Qualified for Work }\end{array}$ & \multicolumn{2}{|l|}{$\$ 800,000$} & \multicolumn{2}{|c|}{ Predicting resource 2016 external support of $\$ 700,000$} \\
\hline Work and income & \multicolumn{2}{|c|}{$\begin{array}{ll}\$ 100,000 & \text { Funding } 1 \\
\$ 40,000\end{array}$} & ed Transferred from other $\mathrm{p}$ & rojects: approximately \\
\hline $\begin{array}{l}\text { Mobile Service } \\
\text { Station }\end{array}$ & \multicolumn{4}{|c|}{$\$ 250,000$ Funding not received Another project funding used } \\
\hline \multicolumn{5}{|c|}{ Project funding not received } \\
\hline $\begin{array}{l}\text { System Municipal } \\
\text { Employment } \\
\end{array}$ & & $\$ 100,000$ & $\begin{array}{l}\text { Centre for Autonomous } \\
\text { Service CAS } \\
\end{array}$ & $\$ 200,000$ \\
\hline \multicolumn{2}{|c|}{ Conferences and debates } & $\$ 100,000$ & Solidarity Economy & $\$ 200,000$ \\
\hline \multicolumn{2}{|l|}{ Labour observatory } & $\$ 300,000$ & & \\
\hline
\end{tabular}

Monitoring was useful also to identify problems, redirection possibilities and improvements to the implementation of strategies. Table 7 summarises the issues raised in these discussions, together with the recommendations (Actions) product of our intervention. Some difficulties were considered out of the scope of Secretary governance, requiring an action/direct decision of the Mayor. Further monitoring workshops are planned. 
Table 7. Difficulties and proposed actions

\begin{tabular}{|c|c|c|c|c|}
\hline \multirow{2}{*}{ Project } & \multirow{2}{*}{$\begin{array}{c}\text { Difficulties } \\
\begin{array}{c}\text { Lack of credibility and knowledge } \\
\text { of business }\end{array}\end{array}$} & \multicolumn{3}{|c|}{ Actions } \\
\hline & & $\begin{array}{c}\text { Divulgation for } \\
\text { entrepreneurs Divulgation } \\
\text { on the site }\end{array}$ & $\begin{array}{r}\text { Realiz } \\
\text { Partn }\end{array}$ & $\begin{array}{l}\text { ation of workshop } \\
\text { rships with class } \\
\text { employers }\end{array}$ \\
\hline \multirow[t]{2}{*}{$\begin{array}{l}\text { Municipal } \\
\text { Employment } \\
\text { System } \\
\text { Responsible: A }\end{array}$} & $\begin{array}{c}\text { Belief that the Worker Support } \\
\text { Centre has only the base the } \\
\text { working class of the job market } \\
\text { labour }\end{array}$ & \multicolumn{3}{|c|}{ Wide institutional campaign for enlightenment activities } \\
\hline & $\begin{array}{l}\text { Lack of political action to } \\
\text { implement the Municipal } \\
\text { Employment System as } \\
\text { prioritization of government }\end{array}$ & \multicolumn{3}{|c|}{ Outside the secretariat governance } \\
\hline \multirow{2}{*}{$\begin{array}{c}\text { Cities Fully } \\
\text { Qualified for } \\
\text { Work } \\
\text { Responsible: H }\end{array}$} & $\begin{array}{l}\text { Lack coordination between the } \\
\text { secretariat and technical schools }\end{array}$ & \multicolumn{3}{|c|}{ Agility in information for replacement of the students } \\
\hline & Abandonment of courses & \multicolumn{2}{|c|}{$\begin{array}{l}\text { knowledge test of the discipline } \\
\text { before the course }\end{array}$} & $\begin{array}{l}\text { Awareness for } \\
\text { citizens }\end{array}$ \\
\hline $\begin{array}{l}\text { Reaching more } \\
\text { work and } \\
\text { income } \\
\text { Responsible: C } \\
\text { and E } \\
\end{array}$ & $\begin{array}{l}\text { Lack improve and intensify } \\
\text { actions }\end{array}$ & \multicolumn{3}{|c|}{ Detailing and articulate actions } \\
\hline $\begin{array}{l}\text { Mobile Service } \\
\quad \text { Station } \\
\text { Responsible: A }\end{array}$ & $\begin{array}{l}\text { Lack release of government for } \\
\text { project execution }\end{array}$ & $\begin{array}{l}\text { Actions such as } \\
\text { Municipal } \\
\text { government in } \\
\text { the neighb'hood }\end{array}$ & $\begin{array}{l}\text { te with } \\
\text { ament }\end{array}$ & $\begin{array}{l}\text { Relationships } \\
\text { and actions with } \\
\text { unions and } \\
\text { associations }\end{array}$ \\
\hline \multirow{5}{*}{$\begin{array}{l}\text { Support to } \\
\text { autonomous } \\
\text { workers } \\
\text { Responsible: C }\end{array}$} & $\begin{array}{l}\text { Lack the prioritization as } \\
\text { government action }\end{array}$ & \multicolumn{3}{|c|}{ Outside the secretariat governance } \\
\hline & $\begin{array}{c}\text { Lack prioritised integration with } \\
\text { other secretariats to implement } \\
\text { the Support to autonomous } \\
\text { workers }\end{array}$ & \multicolumn{3}{|c|}{ Resumption of articulation with secretariats } \\
\hline & Lack interest of the citizens & \multirow{3}{*}{\multicolumn{3}{|c|}{ Monthly clarification campaign }} \\
\hline & Bureaucracy & & & \\
\hline & Lack wide awareness campaign & & & \\
\hline $\begin{array}{l}\text { Solidarity } \\
\text { Economy }\end{array}$ & $\begin{array}{c}\text { Lack of integration between } \\
\text { secretariats with priority as } \\
\text { government action }\end{array}$ & \multicolumn{3}{|c|}{ Outside the secretariat governance } \\
\hline $\begin{array}{l}\text { Eye at work } \\
\text { Responsible: C }\end{array}$ & Lack articulation & $\begin{array}{l}\text { Evaluate the } \\
\text { implementation with } \\
\text { government as a } \\
\text { articulation tool }\end{array}$ & $\begin{array}{l}\text { If there } \\
\text { projec } \\
\text { realloca } \\
\text { the }\end{array}$ & $\begin{array}{l}\text { is money, but the } \\
\text { not be feasible, } \\
\text { ion the money for } \\
\text { ther projects. }\end{array}$ \\
\hline
\end{tabular}


At the end of both workshops, the actors were invited to evaluate the workshop and the planning method applied. The results were positive, there were no problems identified with the method. Overall, the participants confirmed that they did not perceive any problems with associated with the method. This was despite circumstances in which time was short and moderation needed to be done efficiently, which could be said to have detracted somewhat from the quality of the discussions, as the actors did not have enough time to discuss and delve deeper into the issues. Another point of mention was the interval between the two workshops, nine months between the first workshop and the second workshop was considered long because several changes occurred regarding budget issues and corrective actions could have been taken before the projects' situation had worsened.

\section{Conclusions, contributions and limitations of the proposed framework}

The purpose of this paper is to advance a theoretical argument for combing PSMs and to produce an integrated framework, validated via an empirical application. To advance the use of multi-methodologies in operational research (Mingers, 1997a, Mingers, 1997b, Ormerod, 1995, Mingers and Brocklesby, 1997) we have presented a systemic framework of an enhanced Situational Strategic Planning (SSP) model: Soft Situational Strategic Planning (SSSP). Furthermore, a clear contribution of this paper is in combining two 'British born' Problem Structuring Methods (SSM and SCA), with a planning methodology from the other side of the Atlantic that acts as an anchor on to which the appropriate elements SSM and SCA are grafted to form SSSP. The outcomes of the research are illustrated in figures 4 and 5 along with tables 3-7 to which researchers may wish to refer and apply it to other complex situations. As the theorised framework was validated by trialling it through an action research intervention, practitioners will be able to see how it was advantageous in practice and may want to apply it. Both academics researchers and practitioners may make their own contributions to further refinement. The paper is a healthy addition to the current OR/MS research in which a number of systemic methodologies have been adapted and adopted on both sides of the Atlantic (Hindle and Franco, 2009, Franco and Hämäläinen, 2016a, Castellini et al., 2017, Abuabara et al., 2017, Franco and Hämäläinen, 2016b).

To enhance the operational research practice, we tested and applied the proposed model in a case study in a Brazilian municipality. This application contributes to the increasing repository of multi-methodological operational research and management science (Henao and Franco, 
2016, Franco and Lord, 2011, Abuabara et al., 2017, Pollack, 2009). This proposed synthesis aims to be more than just an amalgamation of the three methods. Through the testing of the proposed framework, we have reported on the results of a systemic intervention which is framed and supported by SSP but enhanced by key features of SSM and SCA. This has not been done before and can only enhance OR multi-methodological practice. We hope that this paper may lead the way for further developments in this type of approach, it resonates with recent publications in which Soft OR methods from "outside" the tradition of the soft OR portfolio have been used. For instance, 'Value Focused Thinking', a soft method not too well known in European soft OR circles has been used elsewhere some years (Merrick and Garcia, 2004, Merrick et al., 2005). Value-focused Thinking (VFT) is a creative way to address decision-making problems. It teases out values before giving attention to other aspects of the decision process, including alternative solutions (Keeney, 1996, Keeney, 1992). This approach features development of an 'objectives map' that distinguishes 'means' from 'ends' objectives. In this paper, we have used SSP, and we envisage that this paper will encourage the bringing to the mix of other similar methods.

This paper contributes to the development of theory and the practice of OR/MS: conceptually, we have made the case for combining two PSMs (SSM and SCA) with Matus' SSP, a widely used strategic planning tool applied to governmental planning in Latin America. Through our case study, implemented in one of the Brazilian municipalities, we have demonstrated that grafting some features of soft systems methodology and strategic choice approaches into situational strategic planning enhances the operationalization of the three early moments of the SSP process. We have provided a simple and organised approach, whilst allowing the discussion of important factors not accounted for in traditional SSP. These factors include the cause and effect relationships between problems, a description of the problems and the active participation of stakeholders in planning and feasibility analysis. We propose this revised approach, Soft Situational Strategic Planning method (SSSP) as an alternative to the currently pre-eminent SSP to enhance effectiveness of strategic planning in Municipal Government and potentially wider contexts.

The augmented Soft Situational Strategic Planning framework provides an enhanced structure for public managers. Municipal planning is a complex task and moderators take different approaches, the SSSP framework provides one such alternative for moderators. The approach 
may enhance planning performance through clarity and better organization. Notably, this framework has potential for use in various levels of government, in City Halls of Municipalities and in related secretariats and agencies. It may also be utilised in individual projects that are considered of strategic importance for municipal management. We are also aware that conceptually, the multi-methodological framework considers concepts borrowed from the SCA design mode but not its operational tool, AIDA. This can be a topic for further research to explore in more detail feasible courses of action within selected problems.

\section{Final Remarks and further Research}

Although our application yielded good and welcomed results and recommendations amongst the stakeholders, we believe that for a fully successful application, the political will and full support of senior policy makers such as Mayors, senior officials and planning secretaries is necessary; and lack of this willingness and support will certainly act as strong limitation. This support includes active involvement, requiring their attendance and participation in the planning workshops. Thus, the government body requires a human resources approach that allows flexibility for the provision of time designated to facilitate the process of strategic planning sessions. This is the first time two MS/OR soft methods (SSM and SCA) have been combined with planning strategic tool (Matus' SSP) used in local government planning in Latin America for many years. We would highlight the role of a strong and effective moderation to structure and lead the planning events. These are resource intensive activities, important for the development of effective plans and so this role should not be taken lightly. Strategic planning is practiced at two levels in Local Municipalities, internally focused and externally focused with local communities. The second is less popular for cost and logistical reasons. Our recommendation is to include them in some stages of the process, perhaps at the planning stage, but this could certainly be the focus of further research.

Reflecting on the application of the systemic framework, we believe that our SSSP methodology is sound and useful, incorporating as it does, useful elements of other methods and can lead to effective long-term change. Furthermore, the set of systemic intervention tools, we believe, is also easily assimilated by participants, especially when the moderators have a good understanding of its foundations. This paper provides a route map of SSSP for researchers or practitioners seeking to apply this methodology. In the case of a Secretary without direct contact with the citizen, but with other areas/secretariats of the Municipality, social actors may 
be more restricted to politicians. An isolated action promoted by the Municipal Government is less likely to succeed than an action supported by other actors in the city such as unions, business institutions, representatives of organised civil society, politicians, among others. However, for this participation to take place, it is necessary to change the culture in planning by the municipal governments.

Finally, it is worth stating that to improve the intervention, more case studies could contribute to its development and validation, and that close scrutiny from OR practitioners is needed to develop similar frameworks to minimise limitations. Further research could explore if other PSM could contribute to overcoming the limitations and usefully be grafted into the SSSP general framework for strategic government planning. We hope that this paper will encourage OR researchers and practitioners form both sides of the Atlantic to explore these types of multimethodological practice.

\section{References}

ABUABARA, L., PAUCAR-CACERES, A., BELDERRAIN, M. C. N. \& BURROWESCROMWELL, T. (2017). A systemic framework based on Soft OR approaches to support teamwork strategy: an aviation manufacturer Brazilian company case. Journal of the Operational Research Society.

AGUERRONDO, I. \& XIFRA, S. (2011). La Planificación Estratégica Situacional como método de gobierno. Reorganización de la supervisión educativa en Ecuador. http://www.asociacionag.org.ar/pdfcap/6/AGUERRONDO XIFRA.pdf.

BALDISSERA, A., DENARDI, V., DE FREITAS GÓES \& LEOPOLDO, H. (2012). The Altadir Method of Popular Planning as a management teaching instrument in nursing. Investigación y Educación en Enfermería, 30, 253-259.

BERNAZZA, C. (2006). PhD Thesis La planificación gubernamental en Argentina. Experiencias del periodo 1974-2000 como puntos de partida hacia un nuevo paradigma” Facultad Latinoamericana De Ciencias Sociales -Sede Academica Argentina:

http://municipios.unq.edu.ar/modules/mislibros/archivos/Tesis_Claudia_Bernazza.pdf

CASTELLINI, M., ZANAZZI, J. \& CABRERA, G. (2017). Selecting Working Teams for Information Technology Outsourcing Projects Through a Combination of Methodologies. Pesquisa Operacional, 37, 67-92.

CAZAGRANDE, G. S. \& TEIXEIRA, P. A. (2018). Application of Situational Strategic Planning in the Pharmaceutical Supply Center of a midsize public hospital. Systems and Management, 13, 25-35.

CHECKLAND, P. B. (1972). Towards a systems-based methodology for real-world problem solving. Journal of Systems Engineering, 3, 87-116.

CHECKLAND, P. B. (1981). Systems Thinking, Systems Practice. John Wiley \& Sons Ltd.

CHECKLAND, P. B. (1999). Systems thinking, systems practice; soft systems methodology: A 30 year retrospective, West Sussex, England, Wiley and Sons. 
CHECKLAND, P. B. \& POULTER, J. (2006). Learning for Action: A short definitive account of Soft Systems Methodology and its use for Practitioners, teachers and Students, Chichester, Wiley.

CHECKLAND, P. B. \& SCHOLES, J. (1990). Soft Systems Methodology in Action, Chichester, Wiley.

EDEN, C. \& HUXHAM, C. (1996). Action research for the study of organizations. In: CLEGG, S., HARDY, C. \& NORD, W. (eds.) Handbook of organization studies. London: Sage Publications.

FELIX, R., FELIX, P. P. \& TIMÓTEO, R. (2011). Balanced Scorecard: adequação para a gestão estratégica nas organizações públicas. . Revista do Serviço Público Brasília, $62,51-74$.

FERREIRA, J. S. (2013). Multimethodology in metaheuristics. Journal of the Operational Research Society, 64, 873-883.

FLOOD, R. \& JACKSON, M. C. (1991). Creative Problem Solving: Total Systems Intervention, Wiley.

FRANCO, A. \& HÄMÄLÄINEN, R. (2016a). Engaging with Behavioral OR: On methods, Actors and Praxis. In: KUNC, M., MALPASS, J. \& WHITE, L. (eds.) Behavioral Operational Research: Theory, methodology and practice. Palgrave.

FRANCO, L. \& HÄMÄLÄINEN, R. (2016b). Engaging with Behavioral OR: On methods, Actors and Praxis. In: KUNC, M., MALPASS, J. \& WHITE, L. (eds.) Behavioral Operational Research: Theory, methodology and practice. Palgrave.

FRANCO, L. \& LORD, E. (2011). Understanding multi-methodology: evaluating the perceived impact of mixing methods for group budgetary decisions. Omega, 39, 362372.

FRIEND, J. K. \& HICKLING, A. (2004). Planning under Pressure: The Strategic Choice Approach, Abingdon, Routledge.

GIACOMINI, C. (2008). Planejamento Estratégico Situacional - Introdução ao Pensamento de Carlos Matus, IMAP, Curitiba, Instituto Municipal de Administração Pública.

GONÇALVES, R. C. (2005). Modelos de planejamento: uma difusão planejada. XI Encontro Nacional da Associação Nacional de Pós-Graduação e Pesquisa em Planejamento Urbano e Regional - ANPUR, Salvador, Brasil.

GTZ. (2013). ZOPP - an introduction to the method [Online]. Deutsche Gesellschaft fur Technische Zusammenarbeit. Available: http://pmkb.com.br/uploads/2013/08/gtzzopp-introducao-ao-metodo.pdf [Accessed March 2016].

HENAO, F. \& FRANCO, L. A. (2016). Unpacking multimethodology: Impacts of a community development intervention. European Journal of Operational Research, 253, 681-696.

HINDLE, G. \& FRANCO, L. (2009). Combining problem structuring methods to con- duct applied research: A mixed methods approach to studying fitness-to-drive in the UK. Journal of the Operational Research Society, 60, 1637-1648.

HUERTAS, F. (1996). O método PES: entrevista com Matus, Sao Paulo, Editora FUNDAP.

JACKSON, M. C. (1997). Pluralism in systems thinking and practice. Multimethodology: the theory and practice of combining management science methodologies, 347-378.

KEENEY, R. (1992). Value-focused thinking, Cambridge, MA, Harvard University Press.

KEENEY, R. (1996). Value-focused thinking: Identifying decision opportunities and creating alternatives. European Journal of Operational Research, 92, 537-549.

KELLY, G. W. P. \& WALKER, P. (2004). Community-Level Systems Thinking. The 22nd International Conference of the System Dynamics Society. Oxford. 
LIEBL, F. (2002). The Participant Itomy of complex societal problems and its implications for OR. Journal of the Operational Society, 53, 161-184.

MATUS, C. (1980). Planificación de situaciones. Fondo de Cultura Económica México.

MATUS, C. (1993a). Estrategia y plan, Siglo XXI.

MATUS, C. (1993b). Politica, planejamento \& governo, Brasília, IPEA.

MATUS, C. (1996). Chipanzé, Maquiavel e Ghandi, São Paulo, FUNDAP.

MATUS, C. (1997). Politica, planejamento \& governo, Brasília, IPEA.

MATUS, C. (2005). Teoria do Jogo Social, São Paulo, FUNDAP.

MATUS, C. \& FUNDAP (1996). Adeus, senhor presidente: governantes governados, São Paulo, Editora

MERRICK, J. R. \& GARCIA, M. W. (2004). Using value-focused thinking to improve watersheds. Journal of the American Planning Association, 70, 313-327.

MERRICK, J. R., GRABOWSKI, M., AYYALASOMAYAJULA, P. \& HARRALD, J. R. (2005). Understanding Organizational Safety Using Value-Focused Thinking. Risk Analysis, 25, 1029-1041.

MIDGLEY, G. (1997). Mixing methods: developing systemic intervention. In: MINGERS, J. \& GILL, A. (eds.) Multimethodology: Towards Theory and Practice and Mixing and Matching Methodologies. University of Hull, Centre for Systems Studies.

MINGERS, J. (1997a). Multi-paradigm multimethodology. In: MINGERS, J. \& GILL, A. (eds.) Multimethodology. Chichester: Wiley.

MINGERS, J. (1997b). Towards critical pluralism. In: MINGERS, J. \& GILL, A. (eds.) Multimethodology: the theory and practice of combining management science methodolgies. Chichester: Wiley.

MINGERS, J. (2000). Variety is the spice of life: combining soft and hard OR/MS methods. International Transactions in Operational Research, 7, 673-691.

MINGERS, J. (2001a). Combining IS research methods: towards a pluralist methodology. Information systems research, 12, 240-259.

MINGERS, J. (2001b). Multimethodology: Mixing and matching methods. In: ROSENHEAD, J. \& MINGERS, J. (eds.) Rational Analysis for a Problematic World Revisited: Problem Structuring Methods for Complexity, Uncertainty and Conflict. Chichester: Wiley.

MINGERS, J. \& BROCKLESBY, J. (1997). Multimethodology: Towards a framework for mixing methodologies. Omega, 25, 489-509.

MINGERS, J. \& ROSENHEAD, J. (2004). Problem structuring methods in action. European Journal of Operational Research, 152, 530-554.

MUNRO, I. \& MINGERS, J. (2002). The use of multimethodology in practice-results of a survey of practitioners. Journal of the operational research society, 53, 369-378.

ORMEROD, R. J. (1995). Putting Soft OR Methods to Work: Information Systems Strategy Development at Sainsbury's. The Journal of the Operational Research Society, 46, 277-293.

ORMEROD, R. J. (2014). The mangle of OR practice: towards more informative case studies of 'technical' projects. Journal of the Operational Research Society, 65, 1245-1260.

ORMEROD, R. J. (2017). Writing practitioner case studies to help behavioural OR researchers ground their theories: application of the mangle perspective. Journal of the Operational Research Society, 68, 507-520.

PAUCAR-CACERES, A. (2007). Business Culture and MS methdologies in England and France. PhD, Manchester Metropilitan University.

PAUCAR-CACERES, A. (2010). Mapping the changes in management science: A review of 'soft'OR/MS articles published in Omega (1973-2008). Omega, 38, 46-56. 
POLLACK, J. (2009). Multimethodology in series and parallel: strategic planning using hard and soft OR. Journal of the Operational Research Society, 60.

ROSENHEAD, J. (2006). Past, present and future of problem structuring methods. Journal of the Operational Research Society, 57, 759-765.

SANTOS, P. R. \& BELDERRAIN, M. C. N. (2014). Strategic Choice Approach e planejamento estratégico situacional: uma visão metodológica de auxílio mútua. XLVI SOBRAPO - Simpósio Brasileiro de Pesquisa Operaciona, Brasil, Salvador, BA.

SILVA, S., NIERO, J. \& MAZZALI, L. (2009). O Planejamento Estratégico Situacional no Setor Público - A Contribuição de Carlos Matus. . XII SEMEAD Empreendedorismo e Inovação.

TRIPP, D. (2005). Pesquisa-ação: Uma introdução metodológica. Revista Educação e Pesquisa, São Paulo, 31, 443-466.

VAN VLIET, G. (2006). An introduction to Carlos Matus Strategic Situational Planning: Planificacion Estratégica Situacional (PES) http://agritrop.cirad.fr/551534/ [Retrieved 4 October 2018]. In: SÉMINAIRE RÉFLEXIONS SUR LES APPROCHES

D'ACCOMPAGNEMENT (ed.). Montpellier, 2. 